\title{
Alu and Poet Ankyrine Detection and Quantization in Cell Free Dna of Cancer Patients
}

\author{
Ahmed Darweesh Jabbar', Safa Abdul Ilah Faraj', Tariq Dawood Salman ${ }^{3}$, \\ Sarah Majed Kadhum ${ }^{1}$, Zainab Dhiyaa Jabuori ${ }^{1}$ \\ ${ }^{1}$ Biology Department, College of Science, Wasit University, Wasit, Iraq \\ ${ }^{2}$ Faculty of medicine, Wasit University, Wasit, Iraq \\ ${ }^{3}$ Oncology and Haematology Center, AL-Karamah Teaching Hospital, Wasit, Iraq
}

Email address:

bio.ahmed@Gmail.com (A. D. Jabbar)

\section{To cite this article:}

Ahmed Darweesh Jabbar, Safa Abdul Ilah Faraj, Tariq Dawood Salman, Sarah Majed Kadhum, Zainab Dhiyaa Jabuori. Alu and Poet Ankyrine Detection and Quantization in Cell Free Dna of Cancer Patients. Cancer Research Journal. Vol. 6, No. 2, 2018 , pp. $20-25$. doi: $10.11648 /$ j.crj.20180601.14

Received: December 21, 2017; Accepted: January 15, 2018; Published: March 5, 2018

\begin{abstract}
In this study, specimens of plasma were collected from 96 from patient diagnosed with cancer from Al Karama teaching hospital. Also plasma collected from 25 healthy individual as control. Cell-free DNA (cfDNA) was extracted from $1 \mathrm{ml}$ plasma using high pure viral Nucleic Acid Kit as an alternative to high expensive cfDNA kit. cfDNA extracted according to the manufacturer's instructions, but without the use of carrier RNA. This represent the first recorded method of using viral nucleic acid extraction kit for collection of cell free DNA. Results indicate that all cancer samples show significant increase of cfDNA in compare with control (p 0.01). and this dramatic increase in DNA concentration provide good indicator about health condition. DNA integrity have been checked depending on amplification of Arthrobacter luteus (Alu sequence). Both small (115) and large (247) large Alu stretches have amplified using RT PCR using SYBR green dye. Results shows that integrity of DNA extracted from patients and control are suitable for any further molecular investigation, and short Alu repeats are much less abundant in health individual in compare with cancer patient of all cancer types under study. Depending on these results one can conclude that almost all DNA obtained from normal patients is finely fragmented due to apoptosis action and that's why give very little positive. results in compare with corresponding cancer patient which release large DNA fragments resulted from necrosis and NK/Tc cells activity, which is amplifiable more efficiently. In this work another molecular study conducted to investigate the cancer specific sequences. Since we deals with different cancers type in this study, two types of prostate, ovary, testis expressed protein (POTE Ankyrine) were tested $2 \alpha$ and $2 \beta$. Results shows that almost all healthy group were negative for specific POTE test while cancer patient samples are positive for POTE specific amplification. This results are promising since it could be developed to be a building block of cfDNA cancer tests.
\end{abstract}

Keywords: cf-DNA, Alu Sequences, POTE Ankyrine Gene

\section{Introduction}

Cancer is a leading cause of death worldwide which needs appropriate diagnosis methods. Solid biopsies cannot always be performed since it has invasive characteristic and cannot reflect current tumor dynamics or sensitivity to the treatment. Therefore, it is of great value to develop noninvasive detecting methods that could monitor the real-time dynamics of cancer. Liquid biopsy, of circulating nucleotide acids including, circulating tumor DNA (ctDNA), circulating RNA or microRNAs, could be an ideal method for patients with cancer [1] Most of the nucleic acids (DNA and RNA) in the body are located within cells, but a fair amount of extracellular nucleic acids can also be found circulating in the bloodstream called cell free DNA [2].

The term -free DNA- refers to the compound of DNA fragments detectable in various body fluids,. Plasma or serum are most frequently used for that purpose, However, the 
presence of the free DNA was detected in urine [3], saliva [4], feces [5], synovial liquid [6], cerebrospinal fluid [7] and peritoneal fluid [8]. In the past decade, cell free DNA, or circulating cell free DNA, or cell free circulating DNA, isolated from body fluids such as plasma/serum/urine has emerged as an important tool for clinical diagnostics, The existence of cell free DNA in the human circulatory system has been known since the 1948, when Mandel and Matais managed to prove the existence of nucleic acids in human plasma [2]. Normal concentration of the free DNA in healthy individuals varies from 0 to $100 \mathrm{ng} / \mathrm{mL}$ of blood, on average $30 \mathrm{ng} / \mathrm{mL}$ [9]. Majority of the free plasma DNA is doublestranded and consists of DNA molecules sized 0.18-21 kilo base [10].

An elevated level of circulating cell-free DNA (cfDNA) has been detected in patients under pathologic conditions such as cancer, trauma, stroke, pregnancy, autoimmune disorders, and solid organ transplant [11].

Researchers tested blood samples from various cancer patients and found that ctDNA were present at significantly different levels among the patients with different cancer stages. Specifically, patients with advanced-stages of gastroesophageal, pancreatic, breast and colorectal cancer had a higher level of ctDNA than patients in early stages of those diseases, Several previous studies have reported that fragment sizes of cfDNA are around $166 \mathrm{bp}$, similar to those released by typical apoptotic cells [12]. It has been widely accepted that the deregulation of proteolytic activities involved in apoptosis can lead to therelease of DNA or nucleosomes into the blood circulation [13]. Since this work deals with different cancers type, it really necessary to choose a gene that is present or dominant in different cancer such as: Alu sequence and POTE Ankyrine gene.

The Alu sequence family is a family of repetitive elements in the human genome [14]. Modern Alu elements are about 300 base pairs long and are therefore classified as short interspersed nuclear elements (SINEs) among the class of repetitive DNA elements [15]. The typical structure is 5'Part A- A5TACA6 -Part B - Poly A Tail - 3', where Part A and Part B are similar nucleotide sequences.

Both small (115) and large (247) large Alu stretches have amplified using RT PCR using SYBR green dye and found the cf-DNA in patents higher than control.

While POTE, is expressed in many cancers but only in a limited number of normal tissues (testis, ovary, prostate). POTE Para logs are dispersed among 8 human chromosomes [16]. They evolved by gene duplication and remodeling from an ancestral gene, Ankrd26, recently implicated in controlling body size and obesity. In this work two types of POTE gene being investigated, POTE $2 \alpha$ and POTE $2 \beta$.

Study of cf DNA in patients suggest may be useful; (i) To confirm the presence of cancer such as CRC, breast cancer....etc. (ii) To identify the presence of a recurrence or metastasis during follow-up (iii) prospectively, to identify high-risk individuals.

cf-DNAs might be excellent blood cancer biomarkers, as they may be more informative, specific and accurate than protein biomarkers.

\section{Materials and Methods}

\subsection{Samples Collection}

ninety six blood sample were taken from different cancer patients (46 males and 50 females) with an age ranging between 4 to 88 years and Twenty fife blood samples were taken from apparently healthy people $(7$ males and 18 females). the blood transport to centrifugation at $4000 \mathrm{rpm}$ for 5 minutes to separated plasma from blood. Plasma transport to the eppendorf and stored in deep freezing at $20^{\circ} \mathrm{C}$ till use.

\subsection{DNA Extraction}

cf-DNA was extraction by viral nucleic acid kit III according to the manufacturer's instructions and then DNA stored in deep freezing till use, after that concentration of cfDNA measured by used nanodrob.

\subsection{Primers}

Primers were design by [19] as lyophilized powder in eppendorf tubes $(1.5 \mathrm{ml})$ Specific primers were used in this study were shown in Table 1. Before opening, the tubes were centrifuged at $45000 \mathrm{rpm}$ for 1 minutes to precipitate the lyophilized primers, then Deionized sterile distal water was added to each tube at a volume necessary to get a stock solution of $100 \mu \mathrm{M}(100$ pmole/ $\mu \mathrm{l})$ according to the company's orders, then the tubes were keep warm at $65^{\circ} \mathrm{C}$ for 5 minutes using water bath. The tubes were stored as stock solutions of primers at deep frizzing $\left(-20^{\circ} \mathrm{C}\right)$ till use.

To prepare $100 \mu \mathrm{l}$ of working solution $(25$ pmole/ $\mu \mathrm{l}) 25 \mu \mathrm{l}$ of stock solution was added to $75 \mu$ l of Deionized sterile distal water depending on the general dilution equation: $\mathrm{C}_{1} \mathrm{~V}_{1}=\mathrm{C}_{2} \mathrm{~V}_{2}$.

Real-time ALU-PCR was made. they reaction of RT-qPCR contained $8 \mu \mathrm{l}$ of DNA template and $2 \mu \mathrm{l}$ of primers (forward and reverse primer) of each Alu large fragment 247, small fragment 115 and POTE Ankyrine gene to eppendorf contain SYBR Green Master Mix (Bioneer, Korea) and then add DEPC-distilled water to complete total reaction volume to 20 $\mu 1$.

Table 1. The primer sequences.

\begin{tabular}{ll}
\hline Name of primers & Sequences \\
\hline ALU $115 \mathrm{~F}$ & 5-CCT GAG GTC AGG AGT TC AG-3 \\
ALU $115 \mathrm{R}$ & 5-CCC GAG TAG CTG GGA TTA CA-3 \\
ALU $247 \mathrm{~F}$ & 5-TGG CTC ACG CCT GTA ATC-3 \\
ALU $247 \mathrm{R}$ & 5-CAG GCT GGA GTG CAG TGG-3 \\
Common F & 5-GCA CCA CAC CTT CTA CAA TGA-3 \\
POTE $2 \alpha$ & 5-GTC ATC TTC TCG CGG TTG GC-3 \\
POTE $2 \beta$ & 5-TGT CAC GCA CGA TTT CCC-3 \\
\hline
\end{tabular}

\section{Result and Discussion}

The integrity of cfDNA have being checked by using two sizes of Alu sequence being amplified, small Alu 115 and 
large 247. Alu sequence is the most abundant repeated sequence in the human genome, with a copy number of $1.4 \times$ $10^{6}$ per genome. ALU sequences are short interspersed elements, typically 300 nucleotides in length, that account for more than $10 \%$ of the human genome [17]. ALU elements multiply within the genome in a retro position process through RNA polymerase III-derived transcripts from evolution; also they are important in various physiological actions, such as DNA repair, transcription and epigenetics therefore, qPCR of ALU repeats give an idea about the amplified DNA (size-dependent DNA amplification) [18]. results summarized in Figure 1

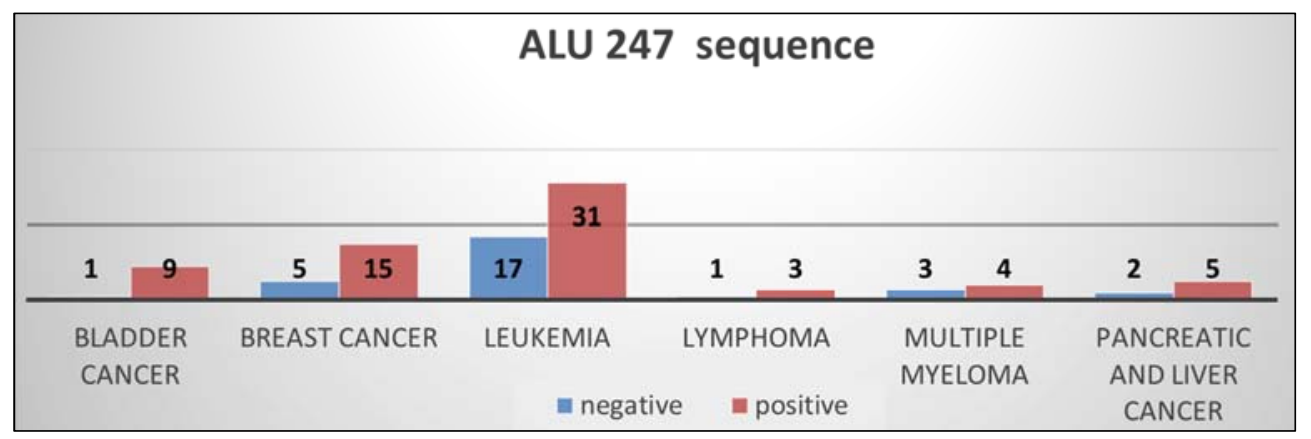

Figure 1. Shows the percentage of Alu 247 sequence for each tumor type.

In control sample Normal cell break down, which is resulted from different mechanisms including ageing of cells, defective developed cells that killed by apoptosis virally infected cells that are killed by natural killer cell directly or antibody mediated cellular cytotoxicity (ADCC) or killing such virally infected cell by action of cytotoxic T cells. in new born and children, a fetal cell free DNA were exist.

In control group, few samples show little bit raised concentration. This may be due to infection, inflammation or elevated temperature. Levels of cfDNA in healthy individuals are low Alu 115 and 247 for control shown in (Figure 2, 3).

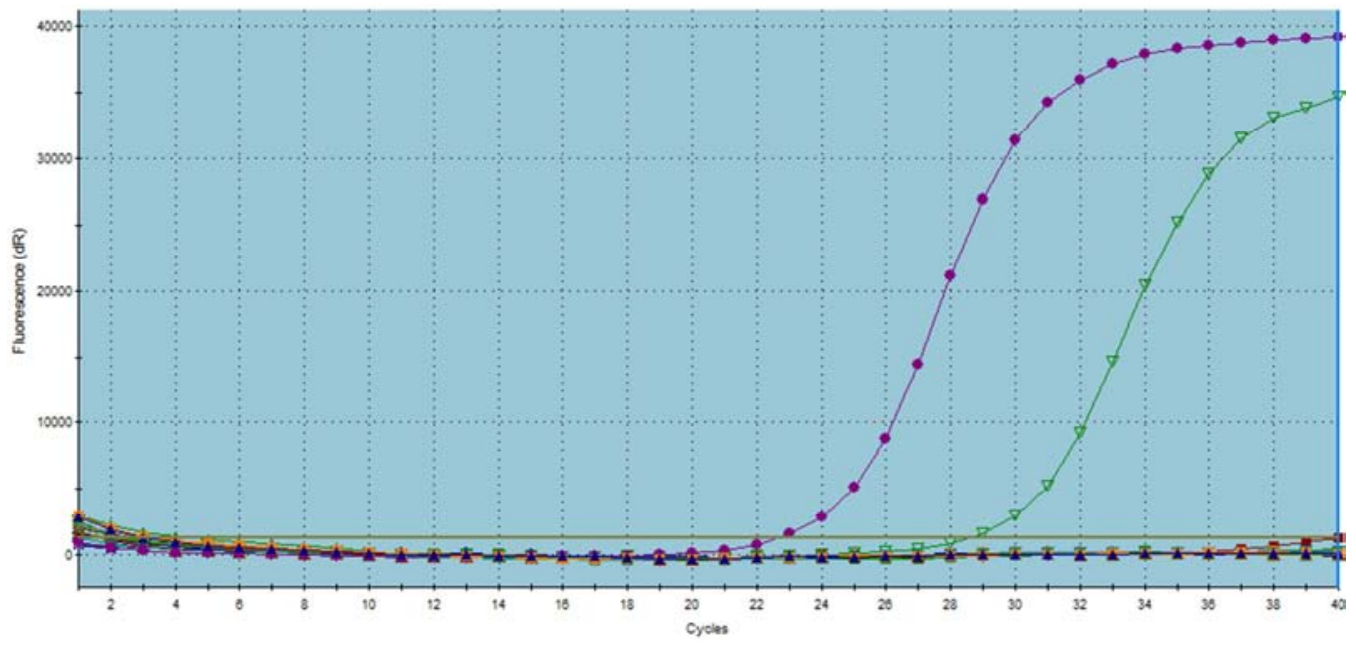

Figure 2. SYBER green -PCR plot of Alu 115 sequence of control. Negative results were under the base line (brown line).

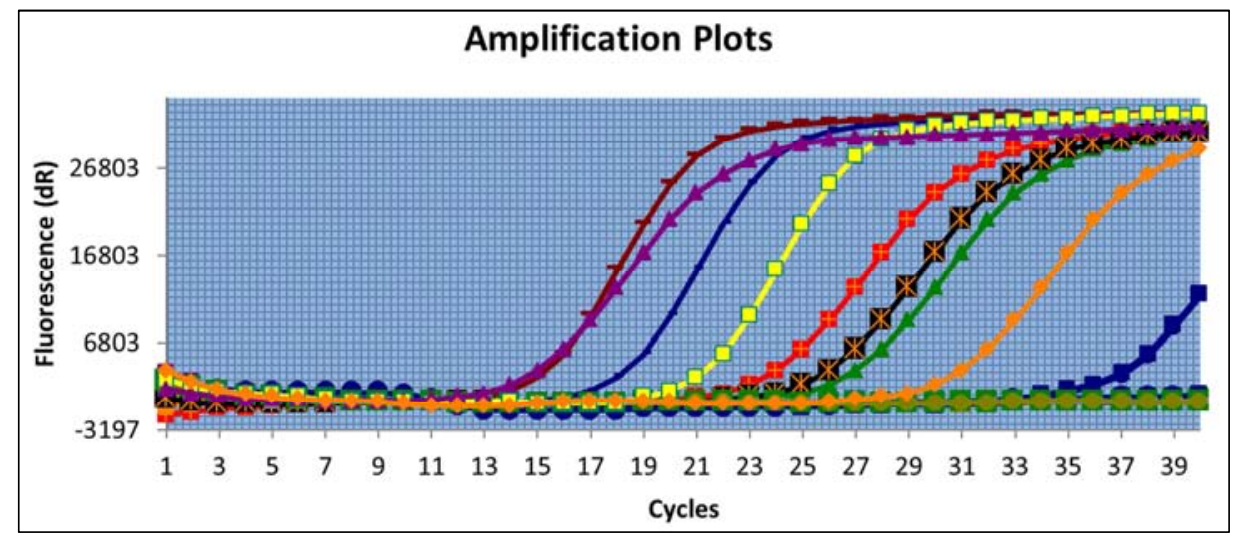

Figure 3. SYBER green-PCR plot of Alu 247 sequence of leukemia patients. Negative results were under the base line. 
In cancer patients, main source of DNA is coming from killing action of NK cells and Tc cells, as well as necrosis and apoptosis. Such cell killing process resulting in production of quite larg DNA sequences result in greater chance of good amplification efficacy (Figure 4, 5).

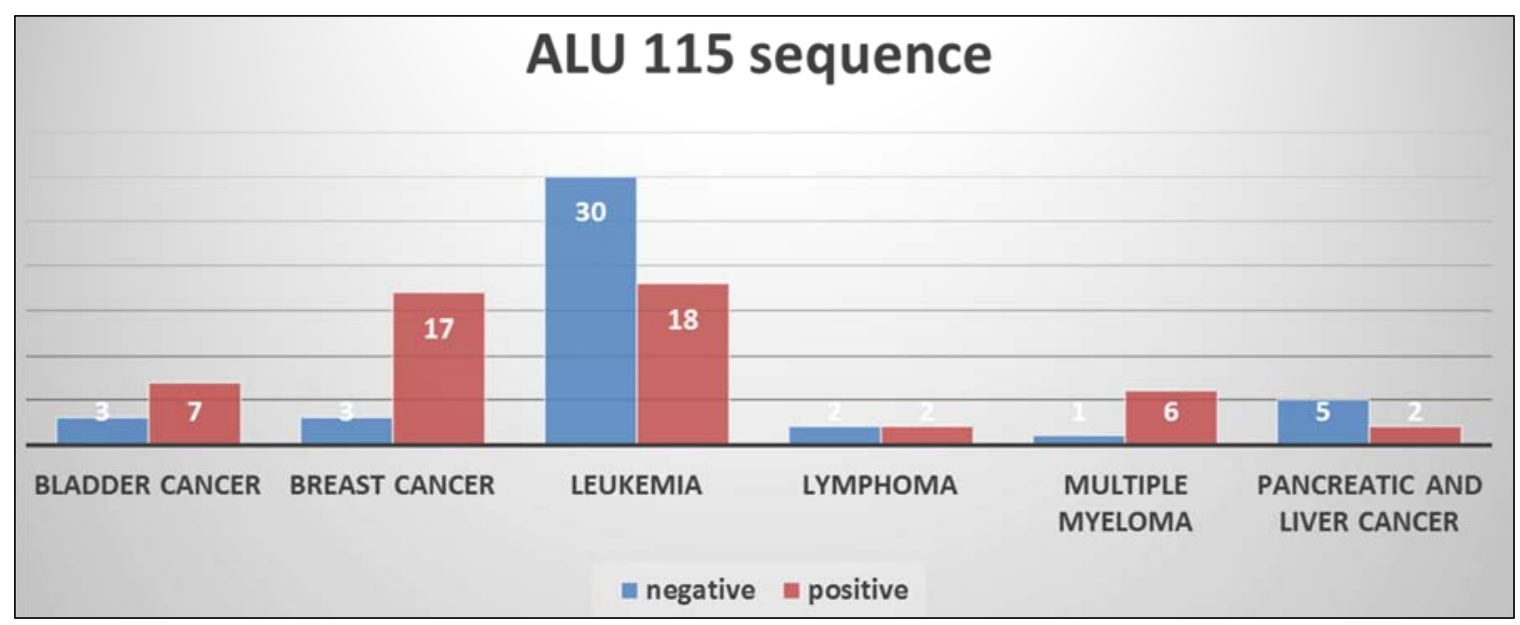

Figure 4. Alu 115 sequence frequency for each cancer patients.

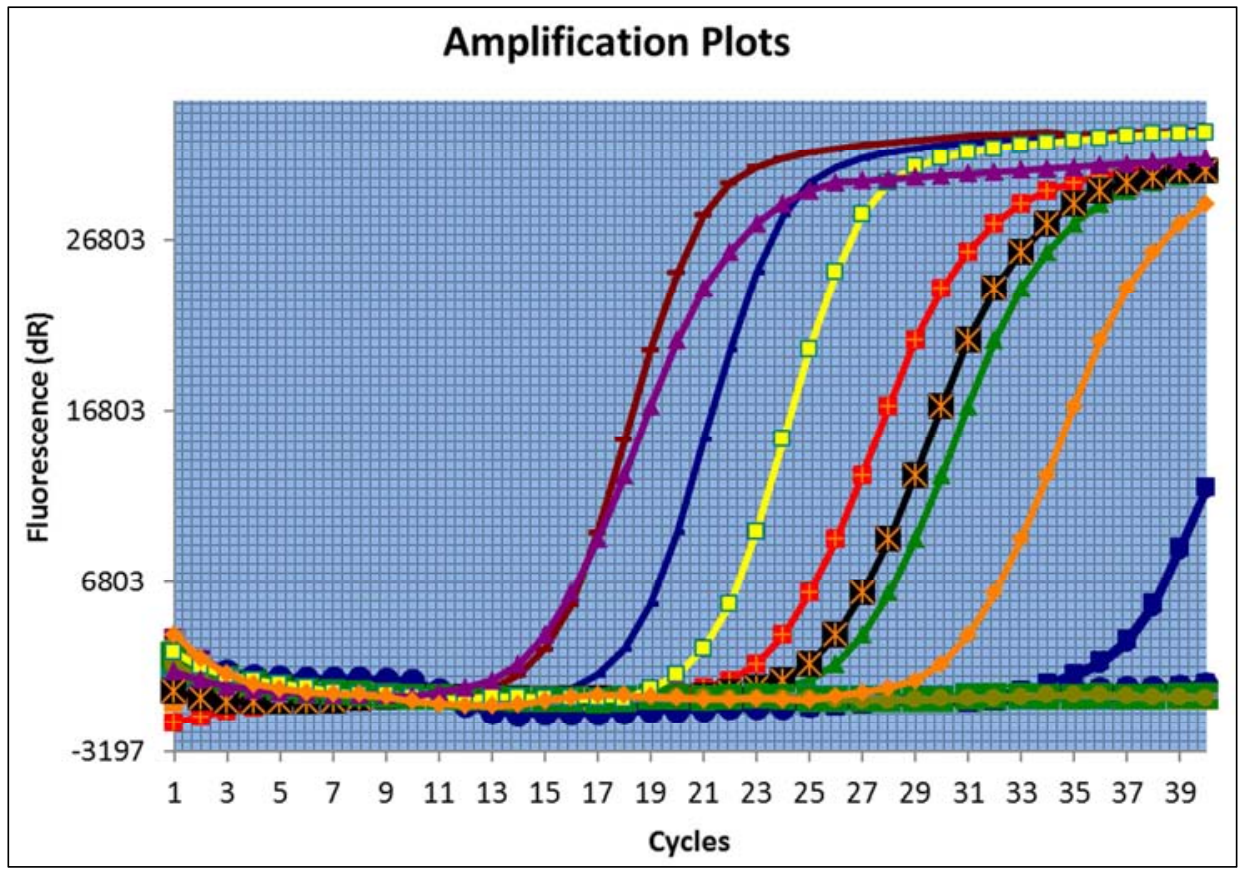

Figure 5. SYBER green -PCR plot of Alu 247 sequence of different cancer patients. Negative results were under the base line.

Investigation of POTE Ankyrine gene

Since this work deals with different cancers type, it really necessary to choose a gene that is present or dominant in different cancer. POTE, is expressed in many cancers but only in a limited number of normal tissues (testis, ovary, prostate). POTE Para logs are dispersed among 8 human chromosomes [16]. They evolved by gene duplication and remodeling from an ancestral gene, Ankrd26, recently implicated in controlling body size and obesity. In this work two types of POTE gene being investigated, POTE $2 \alpha$ and POTE $2 \beta$. Amplification of POTE $2 \alpha$ in control samples shows just one sample is positive, while POTE $2 \beta$ show no positive results in control.

Amplification plot of POTE2 $\alpha$ ankyrine for control is shown in (figure $6,7,8$ ).

In this study POTE ankyrine memebr being tested for all different cancer pateints. This investigation represent firs recorded attempt to study this gene in cell free DNA sampled till know. about $47.9 \%$ (46:96) of sample are posetive for POTE $2 \alpha$ gene, which is considrably high in compare with that of controle, $4 \%(1: 25)$, while only four sample shows posetive POTE $2 \beta$. 


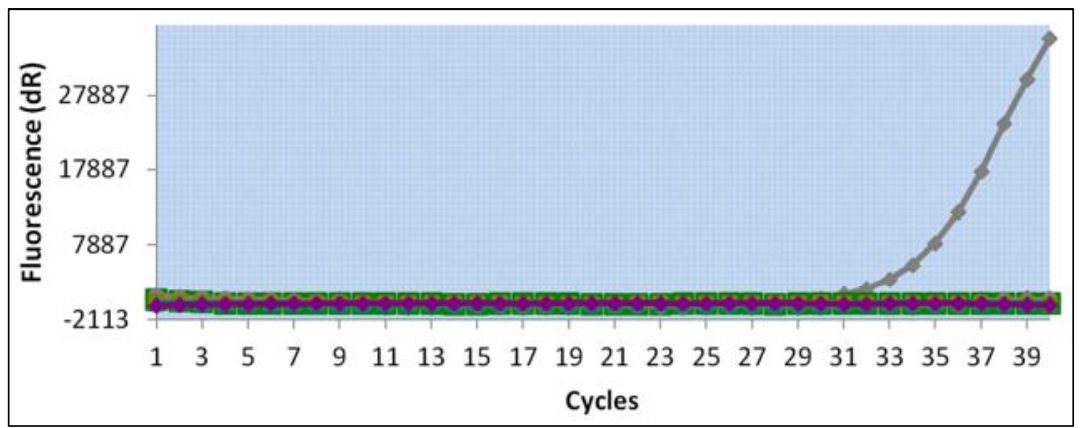

Figure 6. SYBER RT-PCR plot of POTE $\alpha$ gene in control group. Negative results were under the base line.

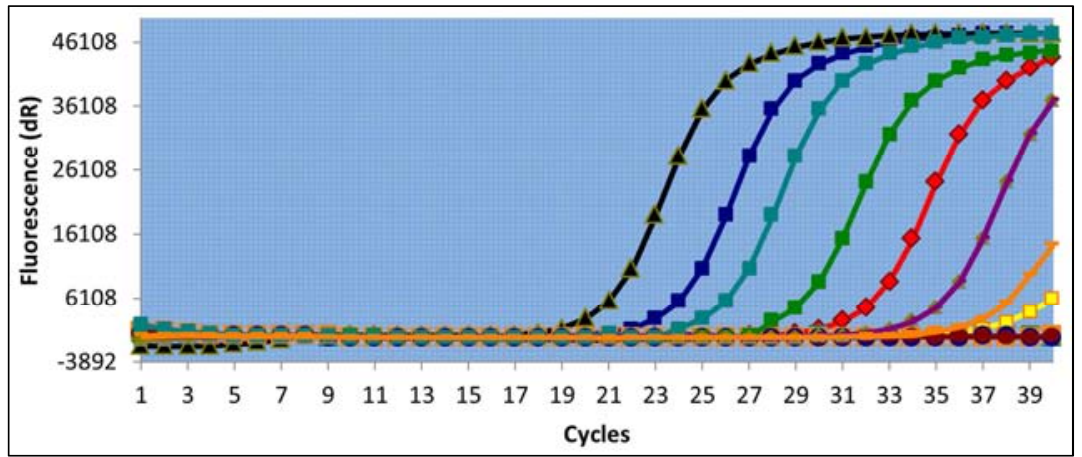

Figure 7. SYBER RT-PCR plot of POTE a gene in different cancer patients. Negative results were under the base line.

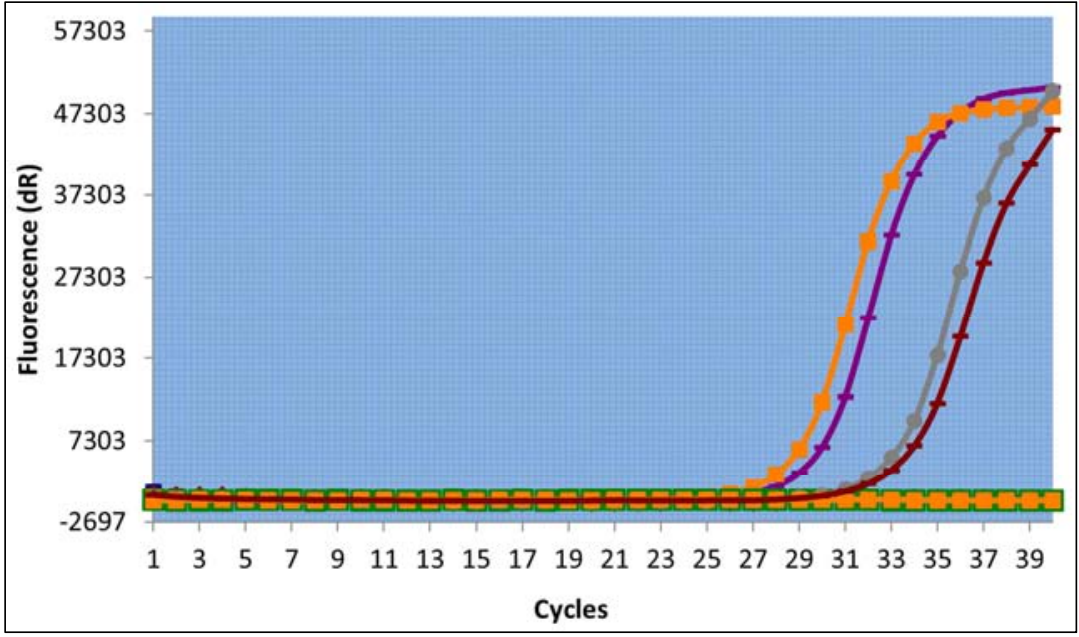

Figure 8. SYBER RT-PCR plot of POTE2 $\beta$ gene.

\section{Conclusions}

DNA concentrations are much less in healthy persons in compare with that of patients. cfDNA concentration give simple idea since it depend on absorbance at 260nm which could be heavy degraded and not suitable for further PCR analysis. Alu repeats give a good idea about the status of extracted cfDNA beside they represent a good marker especially Alu247. It is really important to standardization of cfDNA concentration in different health condition, age and gender is very. Time interval monitoring of cfDNA could be used to check patient on chemotherapy. There is a need for further study to check the possible corresponding between DNA concentration and cancer progression. Cell free provide an opportunity for checking of specific mutation for each cancer could be investigated in future to get more accurate impression about health status. Also, cfDNA could be used as method to study the minimal residual disease of any tumor patient.

\section{References}

[1] Alix-Panabieres C, Pantel K. (2014). The circulating tumor cells: liquid biopsy of cancer. Klin Lab Diagn; (4):60-4.

[2] Mandel, P. and Metais, P. (1948). Les acides nucleiques du plasma sanguin chez l'homme. C. R. Seances Soc. Biol. Fil., $142,241-243$. 
[3] Zhang J, Tong KL, Li PKT, Chan AYW, Yeung CK, Pang CCP, et al. (1999). Presence of Donor- and Recipient-derived DNA in Cell- free Urine Samples of Renal Transplantation Recipients: Urinary DNA Chimerism. Clin Chem; 45:1741-6.

[4] Jiang WW, Masayesva B, Zahurak M, Carvalho AL, Rosenbaum E, Mambo E, et al. (2005). Increased Mitochondrial DNA Content in Saliva Associated with Head and Neck Cancer. Clin Cancer Res; 11:2486-91.

[5] Diehl F, Schmidt K, Durkee KH, Moore KJ, Goodman SN, Shuber AP, et al. (2008). Analysis of Mutations in DNA Isolated From Plasma and Stool of Colorectal Cancer Patients. Gastroenterology; 135:489-98.

[6] Leon SA, Revach M, Ehrlich GE, Adler R, Petersen V, Shapiro B. (1981). DNA in synovial fl uid and the circulation of patients with arthritis. Arthritis Rheum; 24:1142-50.

[7] Rhodes CH, Honsinger C, Sorenson GD. (1994). Detection of tumorderived DNA in cerebrospinal fl uid. J Neuropathol Exp Neurol; 53:364-8.

[8] Hickey KP, Boyle KP, Jepps HM, Andrew AC, Buxton EJ, Burns PA. (1999). Molecular detection of tumour DNA in serum and peritoneal fl uid from ovarian cancer patients. Br J Cancer; 80:803-8.

[9] Anker P, Stroun M. (2000). Circulating DNA in plasma or serum. Medicina (B Aires); 60:699-702.

[10] Jahr S, Hentze H, Englisch S, Hardt D, Fackelmayer FO, Hesch RD, Knippers R. (2001). DNA Fragments in the Blood Plasma of Cancer Patients: Quantitations and Evidence for Their Origin from Apoptotic and Necrotic Cells. Cancer Res; 61 (4):1659-65.

[11] Tokuhisa, Y., Iizuka, N., Sakaida, I., Moribe, T., Fujita, N., Miura, T. et al. (2007). Circulating cell-free DNA as a predictive marker for dis-tant metastasis of hepatitis $\mathrm{C}$ virusrelated hepatocellular carcinoma. British Journal of Cancer, 97, 1399-1403.

[12] Bettegowda C, Sausen M, Leary RJ, Kinde I, Wang Y,
Agrawal N, Bartlett BR, Wang H, Luber B, Alani RM, Antonarakis ES, Azad NS, Bardelli A, et al. (2014). Detection of circulating tumor DNA in early- and late-stage human malignancies. Sci Transl Med.; 6: 2 24-24.

[13] Roth C, Pantel K, Müller V, Rack B, Kasimir-Bauer S, Janni W, Schwarzenbach H. (2011). Apoptosis-related deregulation of proteolytic activities and high serum levels of circulating nucleosomes and DNA in blood correlate with breast cancer progression. BMC Cancer.; 11: 4.

[14] Lander ES, Linton LM, Birren B, Nusbaum C, Zody MC, Baldwin J, Devon K, Dewar K, Doyle M, FitzHugh W, Funke R, Gage D, Harris K, Heaford A, Howland J, Kann L, Lehoczky J, LeVine R, McEwan P, McKernan K, Meldrim J, Mesirov JP, Miranda C, Morris W, Naylor J, Raymond C, Rosetti M, Santos R, Sheridan A, Sougnez C, et al. (2001). Initial sequencing and analysis of the human genome. International Human Genome Sequencing Consortium. Nature, 409:860-921.

[15] Dagan T, Sorek R, Sharon E, Ast G, Graur D (2004). AluGene: a database of Alu elements incorporated within protein-coding genes. Nucleic Acids Res 32: D489-D492.

[16] Bera, T. K., et al.,(2002). POTE, a highly homologous gene family located on numerous chromosomes and expressed in prostate, ovary, testis, placenta, and prostate cancer. Proc. Natl. Acad. Sci. U. S. A. 99, 16975-16980.

[17] Naoyuki Umetani, Joseph Kim, Suzanne Hiramatsu, HowardA. Reber, Oscar J. Hines, Anton J. Bilchik, Dave S. B. Hoon (2016). Increased Integrity of Free Circulating DNA in Sera of Patients with Colorectal or Periampullary Cancer: Direct Quantitative PCR for ALU Repeats. Clinical Chemistry 52:6 1062-1069.

[18] Schwarzenbach, H.; Hoon, D. S. B.; Pantel, K. (2011). Cellfree nucleic acids as biomarkers in cancer patients. Nat. Rev. Cancer, 11, 426-437.

[19] Wang BG, Huang HY, Chen YC, et al. (2003). Increased plasma DNA integrity in cancer patients. Cancer Res 63:39663968. 